\section{British backsliders}

This week's summit meeting of European politicians at Madrid argues for a redefinition of Europe.

THE British are a perpetual source of perplexity to other Europeans, notably those living on the mainland. Do they belong, or do they not? This question was made clamant again this week at the Madrid summit at which eleven heads of government of the members of the European Community (EC) sought to persuade the twelfth - Mrs Margaret Thatcher, the British prime minister - that the British must sooner rather than later decide where they stand on Europe. They will probably have to wait some time before they get a clear answer.

The British themselves, by their long-standing ambivalence towards the mainland, are chiefly to blame. In three decades, there have been three upheavals of opinion about the EC (the rejected application for membership in 1962, the successful application a decade later and the succeeding referendum when British voters were asked whether they wished to continue to belong). Paradoxically, the present government seemed, at its election ten years ago, an enthusiast for membership. In 1984 it signed the amendment to the Treaty of Rome known as the European Single Act, the legislation that will make Europe into a true common market at the end of 1992. Since then Mrs Thatcher, at least, seems to have gone sour on the European project. Her infamous speech at Bruges last year showed that. What has gone wrong?

It is too simple, but probably not irrelevant, to say that Mrs Thatcher and M. Jacques Delors, the president of the European Commission, have little liking for each other. It is also relevant that Britain, now economically in one of its recurrent bad patches, can hardly be expected to act confidently. But what now also seems plain is that Mrs Thatcher, having signed the Single Act, feels impelled in unwelcome directions by some of its implications. That certainly applies to the row at Madrid this week about the European Monetary System, a scheme for permanently linking together the different European currencies with which most EC members have lived cheerfully (and, some say, profitably) for the past decade.

Now M. Delors has mapped out a three-stage programme in which membership of the monetary system would be followed by the creation of a European Central Bank to regulate the monetary system and, eventually, by a common European currency. Mrs Thatcher protests that these are steps towards some distant United States of Europe to which Britain is not committed. But is that so? How could a common market function efficiently if European traders were not able to tell in advance what they would get for what they sold until Europe's banks had converted payments from one currency to another (and taken a cut in the process). The notion that there should be a single currency is a simple consequence of the Single Act. If those who signed that act failed to anticipate that a common monetary policy would be required, who but themselves can they blame?

That is half the story. The more charitable explanation of Mrs Thatcher's discontent with the EC is that it has been put together backwards. The objective of the Treaty of Rome was openly to capture in Europe the economic benefits apparent in great federations such as that of the United States. In the 1950s, it was cheerfully supposed that the task could be accomplished in isolation, without affecting political and administrative arrangements in member states.

What now emerges is what should have been predicted - that economic integration entails other kinds of integration which, nevertheless, need not amount to political integration. The official British position now is that only developments towards the economic goal are allowable - and the definition is being tightly drawn. (Mrs Linda Chalker, Minister of State at the British Foreign Office, said the other day that she was "watching Brussels like a hawk" to make sure that the Commission did not exceed its powers in education, apparently careless of the benefits that might flow from regarding European universities as a common resource.) Other European governments are more sanguine. Mrs Thatcher (who may have misjudged her electorate on the European issue) and her opponents would find future meetings with each other more fruitful if they began at the other end, listing the forms of collaboration outside the strictly economic field that would be mutually beneficial and those implied, but which are not explicit, in the Treaty of Rome and the Single Act. Then, at least, they (and the rest of us) would know the bill of goods.

\section{A most rotten fate}

Sakharov, an angry man, must square his own emotional circle before squaring the Soviet Union's.

Academician Andrei Sakharov, in London last week (see page 651), is both genius and saint. He is also a very angry man, and for good reason. He was illegally exiled to Gorkii by a previous regime and, while there, accused by a shameful number of his colleagues in science of something akin to treason. It is lucky for all concerned, and not just Sakharov, that he was not killed.

But, like the visions of other genius-saints (there have not been many), Sakharov's visions are distant visions. (Augustine's The City of God refers.) He has the cheek to believe not merely that there should already be real democracy in the Soviet Union, but that its ingenious people could solve its impossible economic problems in a day or so. He is right, of course: they could. But they will not. The best hope is that it will take a few more years. His worry, like that of the rest of us, is that it will never happen. Then, of course, we should all be dead. So why not, like a card-player who has figured out that it is possible to win only if the queen of spades is on the left, give fate the benefit of the doubt?

NATURE $\cdot$ VOL $339 \cdot 29$ JUNE 1989 